\title{
Factors affecting the development of food allergy
}

\author{
Ian Kimber* and Rebecca J. Dearman \\ Syngenta Central Toxicology Laboratory, Alderley Park, Macclesfield, Cheshire SK10 4TJ, UK
}

\begin{abstract}
Food allergy is an important health issue. The estimated prevalence among adults in Western Europe is thought to be between 1 and $2 \%$, with the frequency in infants being greater (approximately $5 \%$ ). Most confirmed food allergies are associated with a relatively limited range of produce, including cow's milk, eggs, tree nuts, peanuts, wheat, fish and shellfish, although the prevalence of allergy to individual foods is known to vary geographically, due largely to differences in dietary practices. Although formal evidence is lacking, it is assumed that (in line with other forms of atopic disease) the incidence of food allergy is increasing. There is no doubt that genetic predisposition is an important determinant. However, acquisition of sensitisation to food proteins and subsequent allergic disease is known to be influenced by a variety of environmental factors and the timing, duration and extent of exposure. Moreover, the nature of the allergen itself may have an important impact on the severity and persistence of clinical disease. The purpose here is to discuss the relevance of some of these variables in the context of immunoglobulin $\mathrm{E}$ antibody-mediated allergic responses.
\end{abstract}

\begin{abstract}
Résumé
Les allergies alimentaires représentent un sujet important pour la santé. La prévalence chez les adultes d'Europe Occidentale est estimée entre 1 et $2 \%$, tandis que parmi les enfants elle est plus élevée (autour de $5 \%$ ). La plupart des allergies confirmées sont associées à une gamme de produits relativement réduite, dont le lait de vache, les œufs, les noix, les cacahuètes, le blé, les poissons et les fruits de mer. Cependant, il est connu que la prévalence des allergies aux aliments spécifiques varie selon la zone géographique, en raison principalement des différences dans les habitudes alimentaires. Bien que nous n'en ayons pas la preuve formelle, on suppose que le nombre de cas d'allergie alimentaire, comme celui des autres formes de maladies atopiques, est en augmentation. Il n'y a aucun doute que la prédisposition génétique est un déterminant important. Toutefois, il est connu que l'acquisition de la sensibilisation aux protéines alimentaires et par la suite au problème d'allergie est influencée par un éventail de facteurs environnementaux, ainsi que par le moment, la durée et l'intensité de l'exposition. De plus, la nature de l'allergène lui-même peut avoir un rôle très important sur la sévérité et la persistance de la maladie clinique. Notre objectif est ici de discuter de l'importance de quelques-unes de ces variables dans le contexte des réponses allergiques immunoglobuline E-dependant.
\end{abstract}

Food allergy: Sensitisation: Oral tolerance: Allergen exposure

Food allergy is an important health issue. The prevalence of true food allergy among adults is estimated to be between 1 and $2 \%$, and in infants and young children approximately $5 \%$ (Helm \& Burks, 2000). It is likely that, in common with other forms of atopic disease, the prevalence of food allergy is increasing, although at present definitive data to support this view are unavailable. In Western Europe and the USA most food allergies are associated with a limited range of produce, the most common causes being peanuts, tree nuts, cow's milk, eggs, wheat, fish and shellfish (Sampson, 1988; Young et al. 1994; Bush \& Hefle, 1996; Hefle et al. 1996; Yunginger, 1997). However, the prevalence of allergy to particular foods varies geographically, almost certainly as a function of regional dietary practices and the extent of exposure (Hourihane, 1998). 
The common symptoms of food allergy include nausea and vomiting, abdominal pain, distension, flatulence and diarrhoea, although other organ systems may be involved, such as the skin (acute urticaria and angioedema, and atopic dermatitis) and respiratory tract (allergic rhinitis and asthma) (Sampson, 1999). Occasionally, severe systemic (anaphylactic) reactions are provoked (sometimes only when food ingestion is followed by exercise) and these reactions may prove fatal (Tiles et al. 1995; Pumphrey \& Stanworth, 1996; Sampson, 1999).

\section{Immunology of food allergy}

In the context of pathogenetic mechanisms, it is important to distinguish true food allergy from other types of food intolerance. Food intolerance other than allergy may be defined as reproducible adverse reactions, mediated via non-immunological mechanisms, that are provoked in susceptible individuals following consumption of a particular food or food ingredient. Such reactions may, for instance, be associated with enzyme deficiencies or pharmacological effects (British Nutrition Foundation, 2002). Allergy describes the adverse health effects that may be associated with the induction of a specific immune response. Food allergy is therefore characterised by, and dependent on, the induction of an immune response (of sufficient vigour, and of an appropriate quality) to one or more food proteins.

Although other (cell-mediated) immune reactions may be important in some circumstances, such as in coeliac disease associated with gluten sensitivity, immunoglobulin (Ig) E-dependent mechanisms are implicated in the majority of food allergic reactions. Sensitisation is therefore characterised by the generation of a specific IgE antibody response. Such antibody distributes systemically and associates with tissue mast cells. If the now-sensitised subject is exposed subsequently to the inducing allergen, then an elicitation reaction will be provoked. Antigen will bind to, and cross-link, mast cell-associated IgE antibody, and this process, in turn, will cause mast cell degranulation and the release of both preformed and newly-synthesised mediators (including histamine, serotonin, prostaglandins and leukotrienes) that together initiate inflammation and the symptoms of an allergic reaction at the site(s) of exposure. The initiation and maintenance of $\operatorname{IgE}$ antibody responses are tightly regulated, and dependent on the reciprocal activities of functional subpopulations of T lymphocytes. It has been appreciated for some time that populations of both T-helper (Th) and T-cytotoxic cells display functional heterogeneity, particularly with respect to cytokine secretion patterns. Two main subsets of Th lymphocytes have been described (Th1 and Th2 cells) that develop from common precursors during the evolution of adaptive immune responses. Th1 cells secrete, among other cytokines, interferon $\gamma$ and interleukin 2, whereas the cytokine products of Th2 cells include interleukins 4,5 and 13. Comparable subsets of T-cytotoxic cells have been described with similar cytokine expression phenotypes. The overall quality of an immune response is determined in large part by the balance achieved between Th1 and Th2 cells. This balance is of particular significance with respect to development of atopic allergy; the cytokine products of type 2 cells are required for the generation of $\operatorname{IgE}$ antibody responses and the elicitation of allergic reactions, whereas these processes are antagonised by type 1 cells and their products (Stevens et al. 1988; Mosmann \& Sad, 1996; Kimber \& Dearman, 1997; Corry \& Kheradmand, 1999).

\section{Factors affecting sensitisation}

As indicated earlier, the development of allergic sensitisation requires that specific IgE antibody production is induced, and is dependent on the stimulation of an immune response of the necessary magnitude and of the appropriate quality. Clearly, the size and shape of an induced immune response will be determined by a number of variables, including the nature of exposure (route, extent, duration and timing of exposure), congenital or acquired susceptibility and the characteristics of the food protein itself. These variables are considered later. However, it is instructive first to examine what in broad terms may be the immunological outcomes of exposure to a food protein. It is frequently supposed that there exist two options, priming resulting in sensitisation, or oral tolerance resulting in immunological unresponsiveness. The corollary is that, in operational terms, food allergy is viewed as a breakdown or failure of the induction or maintenance of oral tolerance (Strobel, 1997). Although priming $v$. tolerance is apparently consistent with the clinical pattern of food allergy, in as much as some subjects respond immunologically to a food protein that the majority of consumers tolerate without ill effect, the immunological picture is in reality rather more complicated.

The concept of oral tolerance is well established, and has been studied extensively in rodents (Brandtzaeg, 1996; Strobel, 1997). The immunobiological mechanisms that result in the initiation and maintenance of tolerance have been considered in detail elsewhere (Mowat, 1987; Brandtzaeg, 1996; Strobel \& Mowat, 1998), and a similar review is beyond the scope of the present article. However, it is relevant to note that investigations using experimental systems have revealed that, in mice at least, the effective acquisition of tolerance is dependent on a number of important variables, chief among which are the age (and to a lesser extent the genetic background) of the animal and the nature, dose, uptake and processing of the antigen (Strobel, 1997; Strobel \& Mowat, 1998). Oral tolerance is not an experimental artefact restricted to rodents, the limited evidence available suggests that oral exposure to either chemical or protein antigens can result in immunological hyporesponsiveness in human subjects (Lowney, 1973; Van Hoogstraten et al. 1991; Husby et al. 1994).

Oral tolerance is not an absolute phenomenon, and is best described as immunological hyporesponsiveness, rather than unresponsiveness. Tolerance is most commonly characterised by a reduction is some, but not all, aspects of specific immune function. In general terms it would appear that tolerance in T-cells (and a reduction in cell-mediated immune function), is more readily achieved than B-cell tolerance and an inhibition of antibody responses, although $\mathrm{IgE}$ antibody responses are an exception to this rule. It is considered important that cell-mediated immunity and $\operatorname{IgE}$ 
antibody production are more readily tolerised, with lower doses of antigen and for longer periods, than are other aspects of adaptive immunity, when it is these responses that play pivotal roles in the pathogensis of gastrointestinal allergy (Strobel, 1997).

Given that oral tolerance is rarely complete, it comes as no surprise that food protein-specific IgG antibodies are found in normal subjects with no history of food allergy (Barnes et al. 1983, 1988; Johansson et al. 1984; Barnes, 1995). Indeed, it might be assumed that the elaboration of an $\mathrm{IgG}$ antibody response is the normal consequence of dietary exposure to food proteins in both children and adults (Barnes, 1995). These antibodies appear as early as 3 months of age and increase during the first 5 years of life, at a time when levels of IgE antibody against some childhood allergens such as egg and cows'-milk protein are declining. It is of interest also that food-specific IgG antibody levels appear to be higher in circumstances where there is the opportunity for increased absorption of partially-digested proteins due to a compromised mucosa. The likelihood is, therefore, that $\mathrm{IgG}$ responses to food proteins may represent a normal and beneficial mechanism for clearing proteins or peptides that have been inadvertently absorbed from the gastrointestinal tract.

In summary, therefore, it would appear that operationally the ability to tolerate food proteins, and maintenance of health, does not require the suppression of all immune responses, and that the elaboration of $\mathrm{IgG}$ antibody may in fact serve a useful purpose. An interesting question that arises from this observation is whether the balance between IgG and IgE antibody influences the clinical picture of allergic disease. It is tempting to speculate that in circumstances where there exists a robust $\operatorname{IgG}$ antibody response against a food protein there will be effective competition with IgE antibody for the antigenic substrate. Such competition, if it exists, could provide one explanation for why some subjects with detectable IgE antibody of a food protein may remain asymptomatic, and why there are interindividual differences in the amount to food required to elicit reactions. Similarly, it could be argued that maternal food-specific IgG antibodies might serve to limit the transfer of potential food allergens to the foetus in utero, or during breast-feeding.

Conditions of exposure will have a major impact on the induction of sensitisation. Although it is clear that dietary exposure is the main and most important route, there is no reason to suppose that exposure to food proteins, or to other proteins immunologically cross-reactive with food proteins, will not induce sensitisation such that gastrointestinal symptoms will be provoked on subsequent ingestion. The oral allergy syndrome provides an illustrative example of this process. This syndrome appears to have become more prevalent in recent years, and may affect a substantial percentage of subjects with pollen allergy (Amlot et al. 1987; Pastorello \& Ortolani, 1997). The disease is characterised by an IgE-mediated reaction in the oropharyngeal mucosa provoked by local contact with the relevant food; those foods frequently implicated being fruit and vegetables that contain proteins with epitopes cross-reactive with pollen proteins. The assumption is that in many instances systemic sensitisation was induced by inhalation exposure to pollen. There is reason to suppose also that dermal exposure to sufficient amounts of protein may result in allergic sensitisation.

The importance for sensitisation of the age at exposure is an interesting, but as yet unresolved, issue. There is reason from experimental studies to suspect that the efficiency with which immunological hyporesponsiveness to a dietary protein is induced will be influenced markedly by the age at first exposure, but the relationship is difficult to confirm directly in human subjects. There is currently considerable interest in whether sensitisation may be induced in utero and/or during lactation. Although this concept remains speculative, it has been suggested that T-lymphocyte priming against common antigens may occur as early as the second trimester of pregnancy (Warner et al. 1997). Among the factors that might be important for the development of food allergy in infants are: (1) exposure to food allergens in utero, in breast milk or during infancy; (2) the possible protective effect of breast milk on allergen sensitisation; (3) the immune status of the mother during pregnancy and lactation (and, as discussed earlier, the presence or absence of IgG antibodies that may serve to clear, and reduce the availability of, allergenic proteins); (4) the age at which children are introduced to solid foods (British Nutrition Foundation, 2002).

Although the nature of exposure is a pivotal event in sensitisation, the factor that has the most important influence on the likelihood of sensitisation is genetic predisposition (Rowntree et al. 1985). An atopic phenotype in one or both parents substantially increases the chances of atopy in the infant; however, inheritance from the mother carries a higher risk (Ruiz et al. 1992). Although a predisposition to mount IgE responses per se (atopy) is heritable, the particular proteins against which allergic responses will be mounted appears not to be genetically programmed. It is likely that, against a genetic background of increased generalised susceptibility, it is the conditions of, and age at, exposure that are of greatest importance in determining which food proteins will be recognised.

It is apparent that most, if not all, forms of allergic disease are increasing in prevalence. This change has been too rapid to be accounted for by changes in the gene pool, and it is likely, therefore, that other factors will also affect the susceptibility to sensitisation (Geha, 2000). Although there has been speculation regarding the importance of pollution in this respect, one of the most attractive theories at present is that aspects of modern lifestyle may predispose to atopic allergy (Howarth, 1998). One manifestation of this concept is the 'hygiene hypothesis'. Briefly, the suggestion is that during pregnancy a Th2-type immune phenotype predominates, and that unless the immune system is reorientated toward a Th1 phenotype after birth there will be an increased likelihood of allergic sensitisation. The assumption is that normally such reorientation will be facilitated by microbial challenges, and that improving social conditions and standards of health care in the Western world mitigate microbial reprogramming of the immune system.

Taken together it is possible to discern heritable, developmental and environmental influences on susceptibility to 
sensitisation. In addressing the basis for inter-individual differences in susceptibility to sensitisation the key determinants appear to be genetic background and inheritance of an allergic phenotype, internal and external environments during pregnancy and infancy, and the conditions under which particular foods and food proteins are experienced. If collectively these factors form the basis of individual susceptibility, they do not serve to explain why even in atopic individuals predisposed to mounting allergic responses only a small proportion of food proteins are associated with allergic disease.

\section{Influence of antigen}

It could be argued that in theory any food protein can induce allergic sensitisation, if levels of exposure are sufficient and if an appropriate adjuvant is used. In practice, however, this is not the case: only a minority of food proteins are implicated in clinical food allergy, and our own experimental investigations have revealed that proteins differ substantially in their ability to induce $\operatorname{IgE}$ antibody responses in mice. Thus, under conditions of exposure where, in mice, proteins provoke comparable levels of $\mathrm{IgG}$ antibody production, they vary markedly in their ability to stimulate a specific IgE response (Hilton et al. 1994, 1997; Dearman et al. 2000, 2001; Dearman \& Kimber, 2001). From this perspective the important and intriguing question is what differentiates protein allergens from other proteins that despite being immunogenic fail to elicit an IgE antibody response or cause allergic sensitisation. More succinctly, the question is what physicochemical and biological properties confer on proteins inherent sensitising potential. This subject has recently been reviewed in some detail by ourselves (Huby et al. 2000) and by others (Bufe, 1998; Aalberse, 2000; Bredehorst \& David, 2001), and a detailed consideration of this somewhat complicated area is unnecessary here. It will suffice to list some of the main characteristics of proteins that appear to be influential in determining sensitising activity. These characteristics are: (1) size of the protein; (2) glycosylation status; (3) resistance to proteolytic digestion; (4) overall immunogenicity; (5) the way in which proteins are processed by antigen-presenting cells and the form in which peptides are presented to the immune system.

Collectively these features will determine whether a protein will have the characteristics required to stimulate an immune response of the vigour and quality necessary for the acquisition of allergic sensitisation.

\section{Concluding comments}

It is possible to conclude that the development of allergic sensitisation is determined by a variety of important factors. Individual susceptibility will be governed by heritable predisposing traits, the environment experienced during development and the conditions under which, and the age at which, food antigen is experienced. Superimposed on these factors is the fact that, even in individuals with a susceptible phenotype, proteins vary substantially with respect to their inherent allergenic potential.

\section{References}

Aalberse RC (2000) Structural biology of allergens. Journal of Allergy and Clinical Immunology 106, 228-238.

Amlot PL, Kemeny DM, Zachary C, Parks P \& Lessof MH (1987) Oral allergy syndrome (OAS): symptoms of IgE-mediated hypersensitivity to foods. Clinical Allergy 17, 33-38.

Barnes RM (1995) IgG and IgA antibodies to dietary antigens in food allergy and tolerance. Clinical and Experimental Allergy 25, S7-S9.

Barnes RMR, Barton PG, Doig J, Finn R, Harvey MM \& Johnson PM (1983) Distribution of serum antibodies to wheat gliadin and bovine milk in atopic and non-atopic healthy adults. Journal of Clinical and Laboratory Immunology 12, 175-179.

Barnes RMR, Johnson PM, Harvey MM, Blears J \& Finn R (1988) Human serum antibodies reactive with dietary proteins. IgG subclass distribution. International Archives of Allergy and Applied Immunology 87, 184-188.

Brandtzaeg P (1996) History of oral tolerance and mucosal immunity. Annals of the New York Academy of Sciences 778, $1-27$.

Bredehorst R \& David K (2001) What establishes a protein as an allergen? Journal of Chromatography 756B, 33-40.

British Nutrition Foundation (2002) Adverse Reactions to Foods [J Buttriss, editor]. Oxford: Blackwell Science.

Bufe A (1998) The biological function of allergens: relevance for the induction of allergic disease. International Archives of Allergy and Immunology 117, 215-219.

Bush RR \& Hefle SL (1996) Food allergens. Critical Reviews in Food Science and Nutrition 36, Suppl., S119-S163.

Corry DB \& Kheradmand F (1999) Induction and regulation of the IgE response. Nature 402, Suppl., B18-B23.

Dearman RJ, Caddick H, Basketter DA \& Kimber I (2000) Divergent antibody isotype responses induced in mice by systemic exposure to proteins: a comparison of ovalbumin with bovine serum albumin. Food and Chemical Toxicology 38, 351-360.

Dearman RJ \& Kimber I (2001) Determination of protein allergenicity: studies in mice. Toxicology Letters 120, 181-186.

Dearman RJ, Caddick H, Stone S, Basketter DA \& Kimber I (2001) Characterization of antibody responses induced in rodents by exposure to food proteins: influence of route of exposure. Toxicology 167, 217-231.

Geha RS (2000) Allergy, a disease of the internal and external environments. Current Opinion in Immunology 12, 615-617.

Hefle SL, Nordlee JA \& Taylor SL (1996) Allergenic foods. Critical Reviews in Food Science and Nutrition 36, Suppl., S69-S89.

Helm RM \& Burks AW (2000) Mechanisms of food allergy. Current Opinion in Immunology 12, 647-653.

Hilton J, Dearman R, Basketter DA \& Kimber I (1994) Serological responses induced in mice by immunogenic proteins and by protein respiratory allergens. Toxicology Letters 73, 43-53.

Hilton J, Dearman RJ, Sattar N, Basketter DA \& Kimber I (1997) Characteristics of antibody responses induced in mice by protein allergens. Food and Chemical Toxicology 35, 1209-1218.

Hourihane J O'B (1998) Prevalence and severity of food allergy need for control. Allergy 53, Suppl. 46, 84-88.

Howarth PH (1998) Is allergy increasing? - early life influences. Clinical and Experimental Allergy 28, 2-7.

Huby RDJ, Dearman RJ \& Kimber I (2000) Why are some proteins allergens? Toxicological Sciences 55, 235-246.

Husby S, Mestecky J, Moldoveanu Z, Holland S \& Elson CO (1994) Oral tolerance in humans. T cell but not B cell tolerance after antigen feeding. Journal of Immunology 152, 4663-4670.

Johansson S, Dannaeus A \& Lija G (1984) The relevance of antifood antibodies for the diagnosis of food allergy. Annals of Allergy 53, 665-672. 
Kimber I \& Dearman RJ (1997) Cell and molecular biology of chemical allergy. Clinical Reviews in Allergy and Immunology 15, 145-168.

Lowney E (1973) Suppression of contact sensitization in man by prior feeding of antigen. Journal of Investigative Dermatology 61, 90-93.

Mosmann TR \& Sad S (1996) The expanding universe of T-cell subsets: Th1, Th2 and more. Immunology Today 17, 138-146.

Mowat AM (1987) The regulation of immune responses to dietary antigens. Immunology Today 8, 93-98.

Pastorello EA \& Ortolani C (1997) Oral allergy syndrome. In Food Allergy. Adverse Reactions to Foods and Food Additives, pp. 221-233 [DD Metcalfe, HA Sampson and RA Simon, editors]. Cambridge, MA: Blackwell Science.

Pumphrey RSH \& Stanworth SJ (1996) Clinical spectrum of anaphylaxis in north-west England. Clinical and Experimental Allergy 26, 1364-1370.

Rowntree S, Cogswell JJ, Platts-Mills TA \& Mitchell EB (1985) Development of IgE and IgG antibodies to food and inhalant allergens in children at risk of allergic disease. Archives of Diseases in Childhood 60, 727-735.

Ruiz RG, Kemeny DM \& Price JF (1992) Higher risk of eczema from maternal atopy than from paternal atopy. Clinical and Experimental Allergy 22, 762-766.

Sampson HA (1988) IgE-mediated food intolerance. Journal of Allergy and Clinical Immunology 81, 495-504.

Sampson HA (1999) Food allergy. Part 1: immunopathogenesis and clinical disorders. Journal of Allergy and Clinical Immunology 103, 717-728.
Stevens T, Bossie A, Sanders VM, Fernandez-Botran R, Coffman RL, Mosmann TR \& Vitetta ES (1988) Regulation of antibody isotype secretion by subsets of antigen-specific helper $\mathrm{T}$ cells. Nature 334, 225-258.

Strobel S (1997) Oral tolerance: immune responses to food antigens. In Food Allergy. Adverse Reactions to Foods and Food Additives, pp, 107-135 [DD Metcalfe, HA Sampson and RA Simon, editors]. Cambridge, MA: Blackwell Science.

Strobel S \& Mowat AMcI (1998) Immune responses to dietary antigens: oral tolerance. Immunology Today 19, 173-181.

Tiles S, Schocket AL \& Milgrom H (1995) Exercise induced anaphylaxis related to specific foods. Journal of Pediatrics $\mathbf{1 2 7}$, 587-589.

Van Hoogstraten IMW, Andersen KE, Von Blomberg BME, Boden D, Bruynzeel D, Burrows D, Camarasa JG, Dooms-Goossens A, Kraal G, Lahti A, Menne T, Rycrofy RJG, Shaw S, Todd D, Vreeburg KJJ, Wilkinson JD \& Scheper RJ (1991) Reduced frequency of nickel allergy upon oral nickel contact at an early age. Clinical and Experimental Immunology 85, 441-445.

Warner JA, Jones CA, Jones AC, Miles EA, Francis T \& Warner JO (1997) Immune responses during pregnancy and the development of allergic disease. Pediatric Allergy and Immunology $\mathbf{8}$, S5-S10.

Young E, Stoneham MD, Petruckevitch A, Barton J \& Rona R (1994) A population study of food intolerance. Lancet 343, 1127-1130.

Yunginger JW (1997) Food antigens. In Food Allergy. Adverse Reactions to Foods and Food Additives, pp. 49-63 [DD Metcalfe, HA Sampson and RA Simon, editors]. Cambridge, MA: Blackwell Science. 